\title{
Qualified Immunity as a Defense to Federal Wiretap Act Claims
}

\author{
Kathleen Lockard $\dagger$
}

In 1968 , in response to several high-profile criminal cases involving the surveillance of U.S. citizens without a warrant, ${ }^{1}$ Congress passed Title III of the Omnibus Crime Control and Safe Streets Act of 1968, known as the Federal Wiretap Act ("FWA"). ${ }^{2}$ Before passage of the FWA, Congress saw a gap in federal, state, and local provisions regarding forms of surveillance due to technological innovation. It concluded that the present state of the law was "extremely unsatisfactory" and served. "neither the interests of privacy nor law enforcement." ${ }^{3}$ The FWA embodies the dual purposes of Congress: first, protecting the privacy of wire and oral communications and the integrity of court proceedings; and second, preserving the ability of law enforcement to use taps in legitimate criminal investigations. ${ }^{4}$ With respect to the first goal, the statute provides strict limits on the ability of law enforcement officials to tap suspects without proper approval and authorizes civil suits against officials who violate the Act.'

With respect to the second goal, Congress recognized that wiretapping was an effective evidence-gathering mechanism, in particular against organized crime. ${ }^{6}$ Congress feared that the safeguards it established to protect innocent citizens from wiretapping (limits on unapproved tapping, plus civil suits for violations) could overdeter the use

$\dagger$ B.S.F.S. 1995, Georgetown University School of Foreign Service; J.D. Candidate 2002, The University of Chicago.

1 See Katz v United States, 389 US 347, 353 (1967) (finding government recording of a phone call from a public phone booth was a "search and seizure" under the Fourth Amendment); Berger $v$ New York, 388 US 41, 44 (1967) (finding state statute regarding electronic eavesdropping "too broad" and in violation of the Fourth and Fourteenth Amendments).

2 Title III of the Omnibus Crime Control and Safe Streets Act of 1968, Pub L No 90-351, 82 Stat 212, 223 (1968), codified at 18 USC $\$ 2510$ et seq (1994 \& Supp 1998).

3 Omnibus Crime Control and Safe Streets Act of 1968, S Rep No 90-1097, 90th Cong, 2d Sess 67, reprinted in 1968 USCCAN 2112, 2154.

4 S Rep No 90-1097 at 10-11 (cited in note 3) (discussing the purpose of the FWA and Congress's concerns with the proliferation of tapping of innocent persons, while recognizing the importance of tapping as a tool against organized crime).

518 USC $\$ \S 2511,2520$.

6 See, for example, S Rep No 90-1097 at 70-71, reprinted in 1968 USCCAN at 2157-58 (cited in note 3 ) (noting the need for effective tools to combat organized crime and recognizing that efforts had largely been unsuccessful to that point in combating this "parasite," which was draining an estimated seven billion dollars per year from the economy). 
of wiretapping in bona fide criminal investigations.' Congress did not intend law enforcement officials who attempted to comply with the statute, but for some reason had obtained an imperfect authorization, to face civil liability. Thus, the statute includes a "good faith" defense to protect officials who attempted to comply with the letter of the law, but for some reason beyond their control failed to do so. ${ }^{8}$ Congress did not provide additional guidance for interpreting this "good faith" defense, but courts have generally read the "good faith" requirement to include a subjective inquiry into the belief and motivation of the defendant. ${ }^{9}$

At the time Congress passed the FWA, the good faith defense was adjudicated on terms similar to qualified immunity. ${ }^{10}$ Qualified immunity most often arises in the context of constitutional tort suits against state officials under 42 USC $\$ 1983^{11}$ ("Section 1983") or against federal officials, as first recognized by Bivens $v$ Six Unknown Named Agents of Federal Bureau of Narcotics. ${ }^{12}$ It provides a defense to officials who violated constitutionally protected rights but who acted with a good faith belief that their behavior was permitted. ${ }^{13} \mathrm{Be}$ fore 1982, qualified immunity provided a defense if the official's good faith belief was "reasonable." The defense had two components: (1) subjective, good faith motivation by the official and (2) a requirement that a reasonable person would have known that a constitutional right had been violated. ${ }^{14}$ Early FWA cases confirm that courts treated the subjective evaluation of good faith under both defenses in the same fashion. ${ }^{15}$

In 1982, the Supreme Court in Harlow v Fitzgerald ${ }^{16}$ changed the test for qualified immunity to a purely objective standard. Post-

7 S Rep No 90-1097 at 11 (calling wiretaps "an indispensable aid to law enforcement").

8 See 18 USC $\$ 2520$ (d) (listing "good faith" reliance on imperfect authorization as a complete defense).

9 See, for example, Tapley v Collins, 211 F3d 1210, 1215 (11th Cir 2000) (finding that the good faith defense requires inquiry into the subjective belief of the defendant, and is generally a jury question).

10 See discussion in Part III.A.

1142 USC $\$ 1983$ (1994 \& Supp 1998). See text accompanying note 22.

12403 US 388, 395 (1970) (authorizing damages to remedy Fourth Amendment violation by federal officials).

13 See, for example, Butz v Economou, 438 US 478, 500 (1978) (allowing qualified immunity as a defense to constitutional tort suits); Wood v Strickland, 420 US 308, 314-20 (1975) (discussing qualified immunity as a defense to Section 1983 claims).

14 Wood, 420 US at 322 (1975) (outlining the objective and subjective components of the good faith qualified immunity defense).

15 See, for example, Chagnon v Bell, 642 F2d 1248, 1257 (DC Cir 1980) (analyzing the possibility of a good faith defense under the qualified immunity standard); Kilgore v Mitchell, 623 F2d 631, 633 (9th Cir 1980) ("If the requisites of the statutory good faith defense are met, then the standard for qualified immunity ... is also satisfied.").

16457 US 800 (1982). 
Harlow qualified immunity requires an objective inquiry into whether the right violated was "clearly established," and whether a "reasonable person" would have known this at the time." The FWA good faith defense and qualified immunity were no longer the same. In recent cases, federal circuit courts of appeals have examined whether defendants may assert qualified immunity as a separate defense to alleged FWA violations, reaching divergent and irreconcilable results.

This Comment will examine whether qualified immunity should be available as a defense to FWA claims given that the statute includes its own good faith defense. Part I addresses the basics of qualified immunity, the FWA, and its good faith defense, procedural differences between the two, and principles of statutory preclusion. Part II compares the three recent federal cases discussing the FWA's good faith defense. Part III analyzes older FWA cases and comparable statutes for guidance as to the congressional purpose of the FWA. Part IV proposes that, in light of the purpose of the FWA, defendants should not be able to assert qualified immunity as a defense to FWA civil suits.

\section{QUALIFIED IMMUNITY AND THE FEDERAL WIRETAP ACT}

This Part begins by examining the basics of qualified immunity and its evolution to an objective standard. Next, it discusses the statutory good faith defense provided by the FWA. Then it examines the procedural differences between the two defenses. Finally, this Part concludes by examining statutory preclusion, setting out the basic criteria for finding that a federal common law action is precluded by statute.

\section{A. Qualified Immunity}

Section 1983 provides individuals with a private right of action against state officials to vindicate federally protected rights. ${ }^{19}$ Congress intended Section 1983, enacted as a tool of Reconstruction, to deter states from violating constitutional protections and to provide citizens with a remedial measure. ${ }^{20}$ Section 1983 accomplishes these goals in

17 Id at 818

18 See Part II.A.

19 See 42 USC $\$ 1983$.

20 See Melissa L. Koehn, The New American Caste System: The Supreme Court and Discrimination among Civil Rights Plaintiffs, 32 U Mich J L Ref 49, 54 (1998) ("Congress knew that federal resources were limited and the federal government could not monitor the actions of every state and local government employee, so section 1983 gives the 'man of the street' the ability to enforce his or her own constitutional rights in court."). 
broad language without detail to instruct courts. ${ }^{21}$ The statute states that "[e]very person who, under color of any statute, ... subjects ... any citizen ... to the deprivation of any rights ... shall be liable to the party injured." In Bivens, the Supreme Court allowed the same type of suit under the Fourth Amendment against federal officials to remedy constitutional torts. ${ }^{23}$ Courts adjudicate Section 1983 and Bivens actions on the same basis; the only differences between the two are that Section 1983 is statutory and applies to state officials, while Bivens is a federal common law cause of action that applies to federal officers. $^{24}$

As a remedial regime, Bivens and Section 1983 permit victims to recover damages, although neither provides any guidance on how to value such damages. Jury instructions in these cases instead follow general common law standards for compensatory damages. ${ }^{25}$ The Supreme Court has denied damages for the value of the underlying constitutional violation, so plaintiffs must show an actual injury to recover damages. ${ }^{26}$

Both Bivens and Section 1983 also help to deter future constitutional and statutory violations. ${ }^{27}$ However, there is a tension between the desire to achieve a level of deterrence without paralyzing government operations and the goal of allowing recovery by an individual. The individual remedy tool, if unchecked, could result in a flood of frivolous lawsuits and lead to government paralysis. ${ }^{28}$ Section 1983 contains no statutory defenses to mitigate its breadth. But, in part because of these concerns, the Supreme Court has read Section 1983 "in

21 See 42 USC $\$ 1983$.

22 Id.

23 Bivens, 403 US at 390-92 (rejecting the argument that Fourth Amendment violations by federal agents do not give rise to a federal cause of action). The court allowed Bivens, who had alleged that federal agents searched his home and arrested him without probable cause, to sue for damages based on the alleged Fourth Amendment violation. Id.

24 See, for example, Wilson v Layne, 526 US 603, 609 (1999) (stating that both Section 1983 and Bivens allow plaintiffs to seek money damages against government officials).

25 See Memphis Community School District v Stachura, 477 US 299, 306-08 (1986) (finding that damages in Section 1983 and Bivens actions are solely compensatory damages analogous to those available to remedy common law torts).

26 Id at 308 (stating "the abstract value of a constitutional right may not form the basis for $\S 1983$ damages").

27 See id at 307 (finding that "[d]eterrence is also an important part of [the Section 1983 regime]"). Consider Bivens, 403 US at $407-08$ (Harlan concurring) (stating that deterrence is not the sole reason to permit claims for damages, thus implicitly recognizing deterrence as a reason for awarding damages).

28 See Bivens, 403 US at 430 (Blackmun dissenting) (criticizing the majority's decision, claiming it "opens the door for another avalanche of new federal cases"). See also Crawford-El $v$ Britton, 523 US 574, 601 (1998) (Kennedy concurring) ("[S]uits under 42 U.S.C. $\$ 1983$ can illustrate our legal order at ... its worst.... [M] any of these suits invoke our basic charter in support of claims which fall somewhere between the frivolous and the farcical and so foster disrespect for our laws."). 
harmony with general principles of tort immunities and defenses rather than in derogation of them.," ${ }^{, 29}$ Thus, courts generally allow officials facing such suits to employ the defense of qualified immunity.

Qualified immunity is a long-established common law defense. The purpose of the defense is to allow officials to conduct their duties without "undue interference ... and [shield them] from potentially disabling threats of liability." between competing values, protecting both individual rights and the need for government officials to exercise discretion in the course of performing their jobs. ${ }^{31}$ The defense reflects the judgment that the public interest is best served by allowing for the quick resolution of Section 1983 and Bivens suits, sparing the need for government officials to waste time and money defending themselves against frivolous claims.

Qualified immunity has thus become a fundamental protection for government officials. Courts adjudicate qualified immunity under Section 1983 and Bivens identically. ${ }^{33}$ Until 1982, in adjudicating qualified immunity, courts focused on the good faith belief of the government official alleged to have violated the plaintiff's rights, as well as on the objective reasonableness of the official's actions. In Harlow, the Supreme Court confronted the power of Section 1983 suits, which operate at a "cost not only to the defendant officials, but to society as a whole. These social costs include the expense of litigation, the diversion of official energy from pressing public issues, and the deterrence of able citizens from acceptance of public office. ${ }^{34}$ The Court recognized that qualified immunity was designed to reduce these costs by resolving insubstantial suits at the earliest possible stages of litigation. ${ }^{35}$ The subjective good faith element of the qualified immunity defense prevented the early resolution of cases and thus was not adequately protecting officials who acted reasonably. ${ }^{36}$

The Court therefore abandoned this element and instead switched to an entirely objective inquiry. ${ }^{37}$ Under the objective test, qualified immunity is established unless the right violated was "clearly

29 Malley $v$ Briggs, 475 US 335, 339-40 (1986). By analogy, this principle also applies to Bivens actions.

30 Harlow, 457 US at 806.

31 Id at 807.

32 See Crawford-El, 523 US at 590 (discussing the reasons behind Harlow's switch to an objective standard).

33 See Wilson, 526 US at 609 (stating that courts proceed in the same manner to evaluate qualified immunity in both types of claims).

34 Harlow, 457 US at 814.

35 Id.

36 Id at 815-16.

$37 \quad$ Id at 818 . 
established at the time [the] action occurred," and a "reasonable person" would have known this. ${ }^{38}$ Although this switch de-emphasized Section 1983 as a deterrence tool by increasing the chance that the suit would be dismissed on summary judgment, it allowed the Court to reduce social costs resulting from a flood of insubstantial constitutional tort suits. Because the expected costs of facing such suits decline as a result of the more liberal qualified immunity standard, less deterrence results from the suits in the first place. ${ }^{39}$

\section{B. The Federal Wiretap Act and the Good Faith Defense}

The FWA ${ }^{40}$ gives effect to three principal legislative objectives: it disallows unauthorized wiretapping (Section 2511), prescribes procedures for obtaining authorization to wiretap (Section 2516), and authorizes civil suits to enforce its prohibitions (Section 2520). The detail in the statute supports one of Congress's purposes in enacting the FWA - "to define on a uniform basis the circumstances and conditions under which the interception of wire and oral communications may be authorized." "The legislative history confirms that Congress intended to pass "an essentially comprehensive ban on the interception of oral communications" with detailed procedures. ${ }^{42}$ Further, Congress intended the civil action remedy under Section 2520 of the FWA to be "comprehensive and exclusive.", Courts confirm that the FWA is comprehensive. ${ }^{44}$ Congress's enactment of extremely detailed provisions left little room for augmentation by the judiciary. ${ }^{45}$ When Congress establishes a comprehensive program of federal regulation,

38 Id

39 See Evan J. Mandery, Qualified Immunity or Absolute Impunity?: The Moral Hazards of Extending Qualified Immunity to Lower-Level Public Officials, 17 Harv J L \& Pub Pol 479, 480 (1994) (stating that increasing the likelihood of defendants prevailing on qualified immunity increases the chance that legitimate claims will go unredressed). See also Perry M. Rosen, The Bivens Constitutional Tort: An Unfulfilled Promise, 67 NC L Rev 337, 349 (1989) (stating that the Supreme Court "allows legitimate claims of constitutional violations to go unredressed for the 'greater good"').

4018 USC $\$ 2510$ et seq

41 Omnibus Crime Control Act $\$ 801(\mathrm{~b}), 82$ Stat at 211 . The FWA, as currently amended, includes approximately ten thousand words. The detail of the FWA contrasts with Section 1983, which includes just over one hundred words. Further legislative history confirms that Congress itself thought that the statute enacted was detailed. See S Rep No 90-1097 at 69, reprinted in 1968 USCCAN at 2156 (cited in note 3) (stating that "[ $\mathrm{t}$ ] he need for comprehensive, fair and effective reform setting uniform standards is obvious").

3).

42 See S Rep No 90-1097 at 93, 100, reprinted in 1968 USCCAN at 2181, 2189 (cited in note

43 S Rep No 90-1097 at 107, reprinted in 1968 USCCAN at 2196.

44 See Edwards v State Farm Insurance Co, 833 F2d 535, 538 (5th Cir 1987) (stating that the FWA sets forth "a comprehensive scheme" regulating the interception of communications).

45 See O'Melveny \& Myers v FDIC, 512 US 79,85 (1994) (stating courts should not adopt a court-made rule to supplement a comprehensive and detailed statute). 
little room remains for courts to improve on that program with federal common law.

The FWA prohibits any person from intentionally intercepting, endeavoring to intercept, disclosing, or endeavoring to disclose intercepted contents from any wire, oral, or electronic communication, or using any such contents knowing they were intercepted. ${ }^{47}$ The FWA also prohibits shipping interception devices in interstate commerce, advertising interception devices, and even manufacturing interception devices in certain circumstances. ${ }^{48}$

The FWA also provides detailed procedures for obtaining authorization to wiretap. ${ }^{49}$ This section also contains a lengthy and detailed list of federal crimes for which wiretaps may be obtained. ${ }^{50}$ The statute imposes analogous procedures on states. ${ }^{51}$ The mandatory authorization procedures and list of crimes for which wiretapping may be authorized further indicate Congress's purpose to prohibit a broad range of wiretapping and to limit authorizations to serious law enforcement needs.

Section 2520 authorizes civil suits against any person who contravenes the prohibitions in the statute. ${ }^{52}$ Plaintiffs may sue for equitable relief, damages, punitive damages, and attorneys' fees. ${ }^{53}$ Furthermore, for most violations, Section 2520 specifies that damages are (1) the sum of actual damages and any profits made by the violator as a result, (2) one hundred dollars per day of violation, or (3) ten thousand dollars, whichever is greatest. ${ }^{54}$ Section 2520 therefore provides a strong enforcement mechanism: legal and equitable remedies are available, with minimum damages of ten thousand dollars plus attorneys' fees.

46 See City of Milwaukee $v$ Illinois, 451 US 304,319 n 14 (1980) (stating that "federal courts create federal common law only as a necessary expedient when problems requiring federal answers are not addressed by federal statutory law, [and] the comprehensive character of a federal statute is quite relevant to [whether to preempt federal common law]").

4718 USC $\$ 2511$. While the presumption is that unauthorized interceptions are disallowed, Congress recognized that it had outlawed with a broad brush, and painted narrow exceptions to permit certain necessary types of activities, such as operating switchboards and providing technical assistance to law enforcement officers.

48 Id $\$ 2512$.

49 Id $\$ 2516$. Section 2516 specifies that the Attorney General (or a designee) must approve an application by a federal law enforcement agency to a federal judge for such authorization.

50 Id (including, inter alia, crimes such as espionage, sabotage, piracy, bribery, racketeering, gambling, and money laundering).

51 Id $\$ 2516(2)$.

52 Id $\$ 2520$.

53 Id $\$ 2520($ b).

54 Id $\$ 2520$ (c)(2). Note that 18 USC $\$ 2520(c)(1)$ limits damages when the violation in volves the interception and private viewing of unscrambled or unencrypted satellite or radio transmissions. 
However, Congress also feared that an official who made an honest mistake could face personal liability under the statute. Thus, the FWA provides a "good faith" defense to any suit for damages:

A good faith reliance on-(1) a court warrant or order, a grand jury subpoena, a legislative authorization, or a statutory authorization; (2) a request of an investigative or law enforcement officer under section $2518(7)$ of this title; or (3) a good faith determination that section 2511(3) of this title permitted the conduct complained of; is a complete defense against any civil or criminal action brought under this chapter or any other law.

In order to demonstrate good faith, a defendant must show that he subjectively believed that the wiretap was authorized by a warrant or other means.

The good faith defense was included in the original version of the statute. ${ }^{57}$ From the structure of the statute it is clear that Congress included the defense to guard legitimate law enforcement activities and to protect officials against liability when acting in good faith. ${ }^{58}$ While the good faith defense has been amended several times to clarify the types of authorizations that trigger the availability of the defense, its basic character has never changed. ${ }^{59}$ The good faith defense is the only defense ever included in the statute. The FWA statute is silent as to the availability of other defenses, including qualified immunity.

\section{Procedural Ramifications}

The FWA's good faith defense requires inquiry into the "good faith" of an individual's reliance on a statute or other authorization.

55 Id $\$ 2520(d)$.

56 See Kilgore v Mitchell, 623 F2d 631, 635 (9th Cir 1980) (finding defendant's belief in affidavit's compliance with statute reasonable); Jacobson v Rose, 592 F2d 515, 525 (9th Cir 1979) (finding good faith defense available only if "defendant had a subjective belief which was objectively reasonable that he acted legally pursuant to court order").

57 Omnibus Crime Control Act $\$ 802,82$ Stat at 223 (stating that "[a] good faith reliance on a court order or the provisions of section $2518(7)$... shall constitute a complete defense to any ... action brought under this chapter").

58 Omnibus Crime Control Act $\$ 801,82$ Stat at 211 . Since Congress's purpose was to protect privacy and deter abuses but to allow officials to use wiretaps when authorized, in particular for fighting organized crime, the defense provides cover to law enforcement officers acting in good faith.

59 An interim version of the provision in 1970 stated, "A good faith reliance on a court order or legislative authorization shall constitute a complete defense to any civil or criminal action brought under this chapter or under any other law." District of Columbia Court Reform and Criminal Procedure Act of $1970 \S 211$ (c), Pub L No 91-358, 84 Stat 473, 654 (1970), codified at 18 USC $\S 2520$, amended by the Electronic Communications Privacy Act of $1986 \S 103$, Pub L No $99-508,100$ Stat 1848,1854 (1986). Thus all three versions of the defense provide for "good faith" reliance on a specified authorization to constitute a complete defense to a civil suit brought under the FWA. 
Post-Harlow qualified immunity only requires an objective inquiry into whether the right violated was "clearly established" and whether a "reasonable person" would have known this. ${ }^{60}$ The differences between the two standards have important procedural ramifications.

Post-Harlow qualified immunity allows courts to resolve the immunity question at the earliest stage of litigation. The early resolution of the immunity question benefits both the individual defendant and the general public, as it allows officials to return to their public duties and eases the possibility of overdeterrence. ${ }^{61}$ If qualified immunity is granted at the early stages of litigation, the suit is dismissed, normally without any discovery. As it is critical to resolve qualified immunity at the onset of a case, the Supreme Court has authorized interlocutory appeals from a denial of the immunity defense. ${ }^{62}$ Thus, qualified immunity can spare officials the burden and expense of full discovery and trial, as the Court in Harlow recognized. ${ }^{63}$

As courts adjudicate the FWA good faith defense on a subjective basis, the defense normally requires additional factfinding and discovery. ${ }^{64}$ The inquiry focuses on the individual motivation of the particular defendant. Whether a defendant acted in good faith, a question of credibility and fact, is normally a question that cannot be resolved at the summary judgment stage, but only by the factfinder after trial. ${ }^{65} \mathrm{~A}$ defendant who can assert only the good faith defense bears a higher litigation burden, including discovery. The denial of a good faith defense, in contrast with qualified immunity, may not be the subject of an interlocutory appeal. ${ }^{66}$

\section{Statutory Preclusion}

Qualified immunity is a federal common law defense that may. be precluded by statute. ${ }^{67}$ Federal common law is lawmaking power exercised by courts and Congress may always expressly trump any such

60 Harlow, 457 US at 818.

61 Id.

62 Mitchell v Forsyth, 472 US 511, 530 (1985). Note, however, that the Supreme Court has not extended the right to an interlocutory appeal from the denial of qualified immunity to cases raised in state courts that follow a different interpretation of the collateral order doctrine. See Johnson $v$ Fankell, 520 US 911, 916-18 (1997) (rejecting claim that Idaho must follow Mitchell's definition of "final decision" regarding qualified immunity).

63 See notes 35-39 and accompanying text.

64 See, for example, Tapley v Collins, 211 F3d 1210, 1215 (11th Cir 2000) (stating that "a qualified immunity defense more often can be ... decided earlier in the litigation than a good faith defense").

65 See id.

66 See id.

67 See Part I.A. 
provision through statutory enactments. ${ }^{68}$ When Congress enacts a statute in the same field as a common law provision but remains silent on its continued existence, courts must decide whether the common law coexists with the statute.

Courts have not been entirely consistent when preempting prior federal common law principles. ${ }^{69}$ The Supreme Court sometimes has found that if congressional action on an issue is "comprehensive" and "occupies the field" there is no room for the prior common law principle. ${ }^{70}$ This type of statutory preemption is sometimes called "field preemption." This standard recognizes that if a statute contains specific rules, applying the prior common law principles could result in rewriting those rules. Thus the common law standard is precluded. ${ }^{72}$ This preclusion standard recognizes that the creation of federal common law is extraordinary. ${ }^{73}$ When Congress addresses an area previously governed by federal common law, the need for lawmaking by federal courts disappears. ${ }^{74}$

Other Supreme Court decisions find preclusion only if the statute specifically addresses the question addressed by the common law. ${ }^{75}$ This type of statutory preemption is known as "obstacle preemption." If Congress "speaks directly" to the question addressed by the com-

68 See City of Milwaukee v Illinois, 451 US 304, 314 (1981) (stating "when Congress addresses a question previously governed by a decision rested on federal common law the need for such an unusual exercise of lawmaking by federal courts disappears").

69 Preemption of federal common law by federal statute is generally considered under the rubric of federal preemption of state law, but without the federalism concerns. See, for example, Resolution Trust Corp v Miramon, 22 F3d 1357, 1360 (5th Cir 1994) (stating that arguments raised in support of or against preemption are identical regardless of whether federal or state law is at stake).

70 City of Milwaukee, 451 US at 317-18 (finding that the federal Water Pollution Control Act was comprehensive and preempted federal common law claims).

71 See, for example, Caleb Nelson, Preemption, 86 Va L Rev 225, 227 (2000) (stating that field preemption embodies a finding that a federal regulatory scheme is so comprehensive that no room exists for alternative lawmaking authority).

72 See, for example, Barnes v Andover Co, 900 F2d 630, 637-39 (3d Cir 1990) (finding Congress has not completely preempted federal maritime common law).

73 City of Milwaukee, 451 US at 314 (stating that "[f]ederal common law is a necessary expedient").

74 See Mobil Oil Corp v Higginbotham, 436 US 618, 625 (1978) (refusing common law damages for loss of society in light of Congress's enactment of the Death on the High Seas Act: "The Act does not address every issue of wrongful-death law ... but when it does speak directly to a question, the courts are not free to 'supplement' Congress' answer so thoroughly that the Act becomes meaningless").

75 See, for example, United States v Texas, 507 US 529, 534 (1993) (stating that "[i]n order to abrogate a common-law principle, the statute must 'speak directly' to the question addressed by the common law").

76 See Paul E. McGreal, Some Rice with Your Chevron?: Presumption and Deference in Regulatory Preemption, 45 Case W Res L Rev 823, 832-34 (1995) (stating that obstacle preemption involves trumping state law (or by analogy federal common law) that contravenes Congress's purpose or otherwise interferes with federal regulation). 
mon law, and with contrary purpose, the statute precludes the common law principle. ${ }^{77}$ This standard reflects the understanding that wellestablished common law principles should be retained unless contrary to the purpose of, the statute."

Obstacle preemption analysis is complicated by its reliance on congressional intent. ${ }^{79}$ But assuming that a court can ascertain congressional intent and determine that the federal common law conflicts with that purpose, obstacle preemption allows a court to make the law clearer and more consistent.

When considering whether a statute precludes the application of qualified immunity, courts have sometimes implied an even higher standard. Because some immunities were "so well established" at the time the statute was enacted, statutes will generally not be presumed to preclude them. ${ }^{81}$ Unless Congress clearly indicates the intention to preclude qualified immunity, the defense normally remains available to official defendants. ${ }^{82}$ This type of preemption is normally called express preemption. ${ }^{83}$ Generally, Congress must expressly disallow qualified immunity in order for courts to find preclusion; "occupying the field" is normally insufficient. ${ }^{84}$ The heightened standard in qualified immunity cases reflects an assumption by courts that Congress's intent is best understood as allowing qualified immunity to remain available. Thus, courts normally allow qualified immunity unless expressly preempted. ${ }^{85}$

In determining if a federal common law provision survives a federal statute, whether the court applies a field, obstacle, or express preemption standard, Congress's purpose remains the guiding principle. The court's "role is to interpret the intent of Congress in enacting the

77 See Miramon, 22 F3d at 1361 (finding that a clear statutory standard of gross negligence in the Financial Institutions Reform, Recovery and Enforcement Act preempts federal common law).

78 See United States $v$ Texas, 507 US at 534; Miramon, 22 F3d at 1360.

79 See McGreal, 45 Case W Res L Rev at 833 (cited in note 76) (stating that obstacle preemption requires a difficult inquiry into the policies underlying a statute).

80 Id ("[O]bstacle preemption is part of the larger mission of statutory interpretation to make the law the best that it can be.").

81 See Buckley v Fitzsimmons, 509 US 259, 267-68 (1993) (noting the long history of reading immunities into Section 1983 and presumption against the preclusion of qualified immunity).

82 See id at 268.

83 See Nelson, 86 Va L Rev at 226-27 (cited in note 71) (stating that express preemption occurs when Congress includes a clause specifically trumping the prior state law (or federal common law)).

84 Tapley v Collins, 211 F3d 1210, 1216 (11th Cir 2000) (stating that only a clear and unequivocal statement precludes qualified immunity).

85 See Buckley, 509 US at 268 (stating the presumption that Congress would have specifically provided for the abrogation of traditional immunities had it wished to do that). 
[statute], not to make a freewheeling policy choice." that a statute precludes a federal common law principle, it does so based on the understanding that Congress desires this outcome. The intent of Congress remains paramount, even when deciding if qualified immunity is available under a statute.

\section{FEDERAL Wiretap Act CASES AND Statutory PREClusion}

This Part examines the approach of three different courts in recent cases addressing qualified immunity as a defense to the FWA. The cases employ different reasoning and come to different conclusions. All three examine, at least in passing, the question of whether the FWA's statutory good faith defense precludes qualified immunity. None of the three dispositively resolves the statutory preclusion question.

\section{A. Three Recent FWA Cases}

In Tapley $v$ Collins, ${ }^{88}$ the Eleventh Circuit concluded that defendants may utilize qualified immunity as a defense to FWA claims. ${ }^{89}$ The court allowed the defendant to assert qualified immunity because Congress did not expressly proscribe its use in the FWA. ${ }^{\circ}$ Tapley employed express preemption analysis, and found that qualified immunity remained available."

The Tapley court reached its conclusion by weighing several precedents. The court began with the premise that qualified immunity should apply broadly. ${ }^{92}$ Next, Tapley considered other cases that address the question of qualified immunity under specific statutes. Gonzalez $v$ Lee County Housing Authority ${ }^{93}$ examined qualified immunity as a defense under the Fair Housing Act. ${ }^{94}$ Gonzalez included a comprehensive review of statutes under which courts concluded that qualified immunity remained available. ${ }^{95}$ Relying on the broad appli-

86 Malley v Briggs, 475 US 335, 342 (1986).

87 Id.

88211 F3d 1210 (11th Cir 2000).

89 Id at 1216 (involving chief of police who intercepted cordless telephone conversations and relayed the contents to other city employees).

90 Id at 1215-16.

91 Id.

92 See Buckley v Fitzsimmons, 509 US 259, 268 (1993) (holding that qualified immunity is "so well established" that Congress must specifically abrogate it to result in preclusion); Malley $v$ Briggs, 475 US 335, 340 (1986) (noting that for "executive officers in general ... qualified immunity represents the norm").

93161 F3d 1290 (11th Cir 1998).

94 Id at 1292.

95 Id at 1300 n 34 (including inter alia the Rehabilitation Act of 1973, the Racketeer Influenced and Corrupt Organizations Act, and the Sherman Antitrust Act). 
cation of qualified immunity, statutory analysis from other cases, and the procedural differences between the defenses, the court held that the FWA did not preclude qualified immunity. ${ }^{96}$

The Sixth Circuit took a different approach to qualified immunity under the FWA in Blake $v$ Wright, ${ }^{\text {g7 }}$ but also concluded that qualified immunity was not precluded. ${ }^{98}$ The court held that because qualified immunity was well-established at the time Congress enacted the FWA and nothing in the statute expressly precluded its application, the defense was available. Blake thus uses the express preemption standard to find that qualified immunity remains available.

The court weighed the good faith defense against qualified immunity. Because the good faith defense applies to any defendant, but with a lesser degree of protection, and qualified immunity applies only to government officials, the court concluded that public officials "receive additional protection in responding to constitutional and statutory claims." ${ }^{101}$ Blake equates qualified immunity with absolute immunity and reasons that a judge or a prosecutor should not be stripped of absolute immunity simply because the claim related to a statute that provided an affirmative defense: "[O]fficials performing governmental functions should not lose their qualified immunity because of an affirmative defense which might or might not protect them but would, in all events, require they be subject to extended litigation and deprive them of the benefits of qualified immunity." ${ }^{102}$

The D.C. Circuit took a third approach in Berry $v$ Funk. ${ }^{103}$ Berry held that qualified immunity is not available in FWA claims because of statutory preclusion principles and older FWA precedents. ${ }^{104}$ According to the Berry court, qualified immunity typically applies in cases of constitutionally based claims (or constitutionally based statutory claims such as 42 USC $\$ 1983$ ) that lack specific legislative guid-

\footnotetext{
96 Id at 1300 \& n 35.

97179 F3d 1003, 1006 (6th Cir 1999) (involving a police chief who recorded the conversations of several employees).

98 Id at 1013.

99 Id at 1012.

100 Id at 1013.

101 Id at 1012. While the good faith defense is available to private defendants, by the terms of the defense only private defendants such as a telephone company or bank employees assisting law enforcement with an authorized interception could ever employ it. See Citron $v$ Citron, $539 \mathrm{~F}$ Supp 621, 626 (S D NY 1982) ("[I]t is on reflection self-evident that the good faith defense simply does not apply to actions (civil or criminal) against persons not engaged in law enforcement."), affd, 722 F2d 14 (2d Cir 1983).

102 Blake, $179 \mathrm{~F} 3 \mathrm{~d}$ at 1012.

103146 F3d 1003 (DC Cir 1998) (involving the Department of State Communications Office's monitoring of the phone conversations of a high-level official as part of an investigation of President Clinton). 104 Id at 1013.
} 
ance. ${ }^{105}$ Since the FWA includes a good faith defense that "is more limited than the qualified immunity good faith doctrine," Congress occupied the field. ${ }^{106}$ Thus, qualified immunity may not be used in the FWA context: "When Congress itself provides for a defense to its own cause of action, it is hardly open to the federal court to graft common law defenses on top of those Congress creates." ${ }^{, 107}$ Berry uses field preemption analysis to determine that there is a conflict between qualified immunity and the FWA.

Berry acknowledges that prior cases have, in limited circumstances, allowed qualified immunity as a defense to FWA claims. ${ }^{109}$ In Halperin v Kissinger ${ }^{110}$ and Zweibon $v$ Mitchell ${ }^{11}$ the D.C. Circuit recognized qualified immunity as a defense to FWA claims. ${ }^{112}$ Berry distinguishes those cases as involving a statutory exception under the FWA, since repealed, that preserved the President's constitutional power in the realm of national security. ${ }^{113}$ Because the good faith defense originally required reliance on an "authorization" but the FWA allowed national security wiretaps without authorization, these courts allowed qualified immunity to be raised when this statutory exemption also was raised in order to fill the gap left by the "authorization" requirement in the good faith defense. ${ }^{114}$ According to Berry, the national security area under the FWA was analogous to Section 1983 and Bivens, because it contained gaps requiring judicial interpretation to fill. ${ }^{115}$ But Berry found that where the cause of action arises from activity covered only by the statute (including all FWA cases since 1978), qualified immunity would not be available.

\section{B. The Cases Compared}

These three cases set out the two principal differing lines of analysis for determining whether a defendant may assert qualified

105 Id. Note that Harlow specifically allows qualified immunity for all clearly established statutory claims, not just constitutionally-based statutory claims. Harlow, 457 US at 818.

106 Berry, $146 \mathrm{~F} 3 \mathrm{~d}$ at 1013.

107 Id.

108 Id.

109 Id.

110606 F2d 1192 (DC Cir 1979).

111516 F2d 594 (DC Cir 1975).

112 Berry, 146 F3d at 1013-14. Earlier precedents are considered in greater detail in Part III.A.

113 See 18 USC $\S 2511(3)$ (1970), repealed by the Foreign Intelligence Surveillance Act of $1978 \S 201$, Pub L No 95-511, 92 Stat 1783, 1797; Berry, 146 F3d at 1013-14.

114 Berry, 146 F3d at 1013-14. See also Zweibon, 516 F2d at 671-72.

115 Berry, 146 F3d at 1014 (stating "in cases where defendants raised this exception the doctrine of qualified immunity applied to plaintiff's statutory claims in the same manner as it applied to plaintiff's constitutional claims").

116 Id. 
immunity in the FWA context: One line holds that because the statute does not specifically mention qualified immunity, it is available, while the other finds that because the statute includes a narrower defense, it is precluded. ${ }^{117}$ Upon closer examination, none of the three cases discussed fully addresses the issue or the counterarguments to each holding. Neither Tapley nor Blake addresses the similarities of the defenses, and Berry does not consider the differences.

As discussed above, Tapley concludes that qualified immunity is not precluded based on the doctrine's broad application, express preemption analysis, and the court's survey of other statutes. ${ }^{118}$ But on closer examination, much of Tapley's support is misplaced and does not address the basic question of statutory preclusion. For example, Tapley cites both Buckley $v$ Fitzsimmons and Malley $v$ Briggs to support its conclusion that qualified immunity should apply broadly. While both of these cases recognize the broad constitutional reach of immunity, neither involves the more complicated question of whether immunity is available under a statute that provides alternative affirmative defenses. ${ }^{120}$ These cases only demonstrate the uncontroversial position that qualified immunity is generally available.

Gonzalez is more critical to Tapley's analysis, with its citation of eleven decisions involving qualified immunity under individual statutes. ${ }^{121}$ Gonzalez discussed qualified immunity as a defense to claims under the Fair Housing Act ("FHA"), which includes a good faith defense. ${ }^{122}$ Gonzalez concluded that the FHA did not preclude qualified immunity. ${ }^{123}$ Gonzalez found no indication in the FHA or its legislative history that Congress intended to preclude qualified immunity.

117 One district court case follows a somewhat different line of reasoning. See $\mathrm{McClelland} v$ McGrath, 31 F Supp 2d 616, 619-20 (N D Ill 1998). Because the FWA sets forth "in great detail" the steps that an official must go through to intercept a communication, the immunity would "rarely, if ever, be available" to officers because they would have difficulty asserting a "reasonable" mistake about the statute. Id. Of course, Blake and Tapley suggest otherwise.

118 See text accompanying notes 88-96.

119 Tapley, 211 F3d at 1214, citing Buckley v Fitzsimmons, 509 US 259, 268-69 (1993), and Malley v Briggs, 475 US 335, 341 (1986). While Buckley involves absolute immunity and Malley qualified immunity, there is no relevant difference in analysis based on the different level of protection. See Tapley, 211 F3d at 1214.

120 In Buckley, a prosecutor asserted absolute immunity to a Section 1983 action relating to a criminal prosecution. 509 US at 261-62. In Malley, police officers asserted absolute and qualified immunity to defend alleged violations of Section 1983 by applying for a warrant with bad evidence. 475 US at $337-39$.

121 See text accompanying notes 94-96.

122 The Fair Housing Act states in relevant part, "A person shall not be held personally liable for monetary damages for a violation of this title if such person reasonably relied, in good faith, on the application of the exemption under this subsection relating to housing for older persons." 42 USC \& 3607(b)(5)(A) (1994 \& Supp 1998).

123 Gonzalez, 161 F3d at 1299.

124 Id. 
However, the FHA good faith defense is inapposite to the FWA; the FHA regulates housing discrimination broadly, and the good faith defense applies narrowly to an exemption from certain provisions when considering housing for older persons. ${ }^{125}$ The claim in Gonzalez, under Section 3617 (prohibiting interference with or threatening anyone enjoying rights or encouraging others to assert rights protected by the FHA), could not involve that good faith defense. ${ }^{126}$ Gonzalez's analysis of qualified immunity does not reference the good faith defense, and the court concluded that qualified immunity is available under the FHA without discussing the possibility of preclusion. ${ }^{127}$ Gonzalez does not involve a broad statutory affirmative defense that was available against the claims asserted in the particular case. Finally, Gonzalez's review of other cases and statutes, including, inter alia, the Rehabilitation Act of 1973, the Food Stamp Act of 1977, and the Racketeer Influenced and Corrupt Organizations Act, does not include any claims brought under a statute that provides a good faith (or similar) defense. ${ }^{128}$ Neither Gonzalez nor its eleven precedents provide the close parallel to the FWA that Tapley asserts.

Tapley also fails to address the preclusion argument on its face. While the Tapley court is correct that qualified immunity generally applies broadly, the court does not acknowledge that a broad, statutorily provided affirmative defense, available to defendants in the particular case, complicates preclusion analysis. Tapley's analysis begins and ends with the conclusion that the defenses are not the same. ${ }^{129} \mathrm{Ta}$ pley applied the express preemption standard without considering whether obstacle or field preemption could have been appropriate. ${ }^{1.3}$ Tapley does not consider the possibility that Congress's goals in the FWA may be relevant to the preclusion analysis under these circumstances, namely when a statute includes a broad affirmative defense. As Buckley stated, the court's role is to "interpret the intent of Con-

125 Compare 42 USC $\$ 3607(\mathrm{~b})(5)(\mathrm{A})$ with 18 USC $\$ 2520(\mathrm{~d})$.

126 Contrary to the assertion in Tapley, the good faith defense under the FHA did not factor into the Gonzalez court's decision that qualified immunity was available as a defense to the Section 3617 claim. See Tapley, 211 F3d at 1214-15; Gonzalez, 161 F3d at 1299-1300 (failing even to mention Section 2607 and its statutory good faith defense).

127 Gonzalez, 161 F3d at 1299-1300.

128 See, for example, Affiliated Capital Corp v City of Houston, 735 F2d 1555, 1569-70 (5th Cir 1984) (finding qualified immunity for mayor of Houston in antitrust suit under Section 1 of the Sherman Act). Other cases, not discussed in Gonzalez, involve statutes into which courts 1 ave read good faith requirements. See for example, Lang $v$ Retirement Living Publishing Co, 949 F2d 576, 581, 583 (2d Cir 1991) (examining the good faith of alleged Lanham Act violator as part of court-created eight-part test to determine likelihood of confusion between trademarks).

129 Tapley, 211 F3d at 1215 (stating that "qualified immunity and the good faith defense in the Federal Wiretap Act are not equivalent defenses").

130 Id. 
gress in enacting [the statute], not to make a freewheeling policy choice." ${ }^{131}$

Blake also concludes that there is no preclusion of qualified immunity, but it does not address the specifics of the FWA good faith defense. Blake treats the good faith defense as a generic affirmative defense in its preclusion analysis. ${ }^{132}$ The Blake court also utilizes the express preemption standard. ${ }^{133}$ The court frames the question in terms of government officials' entitlement to qualified immunity, rather than congressional purpose or overlap between the statute and common law. ${ }^{134}$ Blake concludes only that public officials must be entitled to special protections. Further, while Blake criticizes Berry for failing to recognize that government officials generally receive special protection through qualified immunity, it fails to recognize that the good faith defense applies only to a narrow category of civil cases, and reading qualified immunity into the statute renders the good faith defense largely superfluous. ${ }^{135}$ Because the FWA statute does not expressly state that qualified immunity is precluded, Blake concludes that it cannot be, without looking to the best reading of the statute or even its legislative history. Thus, Blake considers the absence of express language in the statute to resolve the issue.

Berry's focus on statutory/constitutional distinctions and short statutory preclusion analysis also does not present the full picture. Berry does not seriously consider the procedural differences between the defenses. It does not address Blake's concern that Congress may have intended for government officials to have preferential treatment. Berry also does not acknowledge that the standard for preclusion of qualified immunity may be more difficult to meet than other federal common law standards. Berry applies the relatively easy-to-satisfy field preemption standard without considering whether obstacle preemption could have been more appropriate. Thus, the court finds pre-

131 Buckley, 509 US at 268, quoting Malley, 475 US at 342.

132 Blake, 179 F3d at 1012 ("[W]e find that simply because [the FWA] provides a defense to wiretap violations does not necessarily imply that qualified immunity ... . does not apply to this ... violation.").

133 Id.

134 Id (stating that "courts, by adopting qualified immunity as a defense for public officials only, have signaled that public officials indeed receive additional protection").

135 Compare Blake, 179 F3d at 1012, with Citron v Citron, 539 F Supp 621, 626 (S D NY 1982) (stating " $[t]$ he [good faith] defense is instead available [primarily] to law enforcement personnel"). Similar reasoning to Blake underlies Peavy v Dallas Independent School District, 57 F Supp 2d 382 (N D Tex 1999). The court concluded that because Harlow unequivocally provides that qualified immunity is available for statutory claims and nothing in the FWA specifically says that the defense is not available to a civil defendant, the defense is available under the FWA. Id at $390-91$. 
clusion without considering the Supreme Court's expansive language establishing a presumption in favor of retaining qualified immunity."

Thus, none of the cases in this trio persuasively resolves the statutory preclusion question. Each of the three courts considers principally the arguments that favor its conclusion. Putting the three analyses together reveals that the availability of qualified immunity as a defense to FWA claims presents a complex question of statutory analysis and preclusion. It is clear, as Blake and Tapley state, that qualified immunity applies broadly. Using the generous field preemption standard, as in Berry, requires the conclusion that qualified immunity is precluded. In conducting their preemption analyses, none of the FWA trio considers which preemption standard best reflects congressional intent under the statute. None of the FWA trio considers the relevance of the obstacle preemption standard, that is, whether qualified immunity is consistent with the purpose of the FWA.

\section{ANALYZING SIMILARITIES AND DIFFERENCES: FWA CASES, GOOD FAITH PROVISIONS IN OTHER STATUTES, AND COMMENTARY}

To resolve the question of whether qualified immunity is precluded in FWA claims, this Part examines historical cases and good faith provisions in other statutes. None of the three recent cases provides a comprehensive historical overview of the two defenses. The preclusion question is more complicated than any of these cases acknowledge. The approaches taken in older cases and under parallel statutes suggest employing obstacle preemption analysis in the FWA context.

\section{A. Pre-1982 Cases Comparing Qualified Immunity and the Good Faith Defense}

When Congress passed the FWA in 1968, courts adjudicated both the statutory defense and qualified immunity on a subjective, good faith basis. The only substantive difference between the defenses, until 1982, was the express requirement in the FWA statutory defense that defendants rely on a "court order or legislative authorization." Courts interpreting both defenses under the FWA fell into two groups. One group, examining cases in which the defendant relied on a court order, found that the defenses were equivalent. The second group, examining cases in which the defendant did not rely on a court order or legislative authorization, found that in general, the good faith defense was narrower than qualified immunity, and except for a narrow statu-

137 See District of Columbia Court Reform and Criminal Procedure Act $\S 211$ (c), 84 Stat at 654. Note that the original version of the provision controlled from 1968 to 1971 . See note 59. 
tory exemption involving national security, defendants could not rely on qualified immunity. This analysis, finding qualified immunity unavailable unless identical in result to the statutory defense, is consistent with employing obstacle preemption analysis to determine if qualified immunity remains available.

The first group of cases includes Kilgore $v$ Mitchell, ${ }^{138}$ in which the plaintiffs alleged wiretapping violations and sought damages under both the FWA and the Fourth Amendment. ${ }^{139}$ The court found that the defendants satisfied the statutory defense to the FWA claim based on their reliance on a letter from the Attorney General authorizing the tap. $^{1.0}$ With respect to the Fourth Amendment claim, the court held that "[i]f the requisites of the statutory good faith defense are met, then the standard for qualified immunity as a defense to Fourth Amendment violations is also satisfied." with reliance on a court order or legislative authorization, the court concluded that both the statutory good faith defense and qualified immunity were met; good faith reliance on an authorization by definition met the acting in reasonable good faith belief standard for qualified immunity. ${ }^{142}$

In evaluating a qualified immunity defense under a national security wiretap, another court equated the defenses, noting that "[a]s to the immunity issue at the heart of this case, the immunity available to the Attorney General under $\S 2520$ of Title III is in any case identical to the common law good faith defense applicable to appellants' Fourth Amendment claim.",143

In Jacobson $v$ Rose, ${ }^{144}$ the Ninth Circuit equated the defenses when considering the case of defendants who had relied on a court order. ${ }^{145}$ The court examined the legislative history and found that while " $\$ 2520$ does not define 'good faith,' the Senate Report on the unamended version of $\S 2520$ suggests an analogy to the good faith defense allowed in $\S 1983$ cases." ${ }^{146}$ Thus, the court equated the two defenses, and concluded that the defendants could satisfy the defense only by demonstrating a reasonable good faith belief that their actions were legal, ${ }^{147}$ the same standard that applied to qualified immunity.

138623 F2d 631 (9th Cir 1980).

139 Id at 632 .

140 Id at 634.

141 Id at 633 (footnote omitted).

142 Id.

143 Chagnon v Bell, 642 F2d 1248, 1260 n 22 (DC Cir 1980).

144592 F2d 515 (9th Cir 1978).

145 Id at 523.

146 Id (footnotes omitted).

147 Id. 
However, the court found the defenses equivalently satisfied under facts in which the defendants met the statutory requirement of reliance on a court order. ${ }^{14}$

The second group of cases, finding differences between the good faith defense and qualified immunity when the defendant did not satisfy the authorization requirement, includes Zweibon. In Zweibon, the court noted that the literal language of the statute required good faith reliance on a court order or legislative authorization. ${ }^{149}$ However, because the case involved executive surveillance, which did not necessarily require a warrant according to Section 2511(3) of the 1970 version of the FWA, ${ }^{150}$ the language of the defense could not be read literally:

[W]e do not perceive the relevant standard of good faith in this case to be that literally specified in Section 2520; rather, we find that a good faith defense to liability, whether under the Bivens rationale or the statutory theory, will be established if appellees can demonstrate (1) that they had a subjective good faith belief that it was constitutional to install warrantless wiretaps under the circumstances of this case; and (2) that this belief was itself reasonable. ${ }^{151}$

Thus in the narrow area of national security executive action, instead of allowing defendants to assert qualified immunity, the court read the good faith defense as equivalent to qualified immunity. Zweibon conformed the statutory defense to qualified immunity because of its concern that the defendants would be left without any affirmative defense. ${ }^{153} Z$ weibon does not permit the defendants to assert common law qualified immunity as a defense to the FWA statute. ${ }^{154}$ The holding of $Z$ weibon was limited to the circumstances of the case, involving executive action and national security. ${ }^{155}$ Zweibon's holding, that qualified immunity and the good faith defense are equivalent under national security wiretap cases, was followed by other courts.

148 Id at 523-24.

$149516 \mathrm{~F} 2 \mathrm{~d}$ at 670 (noting, however, that the clause was amended to allow reliance on a legislative authorization in 1970 , after the relevant facts of the case).

150 See text accompanying notes 113-16.

151 Zweibon, 516 F2d at 670-71 (footnotes omitted).

152 Id at 672-73 (holding that "under the circumstances of this case, the proper statutory good faith defense is identical with the common law good faith defense that would apply to the Bivens cause of action").

153 Id at 672.

154 Id at $672-73$.

155 Id at 671-73. See also text accompanying notes 111-16.

156 See Halperin, 606 F2d at 1208-09. In Halperin, the D.C. Circuit ruled that defendants could utilize qualified immunity on both Fourth Amendment and FWA claims under the reasonable, good faith standard. While Halperin applies "qualified immunity," it purports to follow $Z$ weibon in finding the statutory good faith defense and qualified immunity equivalent. See id at $1209 \mathrm{n} 115$. 
Thus, courts recognized that the statutorily provided good faith defense, as written, could not apply to situations where officials did not rely on some kind of authorization. Zweibon read congressional intent in the FWA to allow defendants an affirmative defense based on qualified immunity because of the complicated national security exemption. Zweibon implicitly employs obstacle preemption analysis -it allows the defense because, in the national security arena, permitting defendants to use qualified immunity comports with the purpose of the statute. Zweibon's conclusion, that qualified immunity was available only under the subsequently repealed national security provision, does not imply that qualified immunity would be available under the FWA today.

In Campitiv Walonis, ${ }^{158}$ the First Circuit did not permit use of the good faith defense to coexist with qualified immunity under the FWA. The court rejected the defendants' attempt to claim the good faith defense under Section 2520 "by grafting onto this section of the statute the good faith immunity defense afforded police officers in 42 USC $\S$ 1983 civil rights actions." fense was equivalent to common law qualified immunity, using the legislative history of the statute as support. ${ }^{160}$ The court rejected that claim because the plain language of the FWA defense required reliance on statutory (or court) authorization to satisfy the defense. ${ }^{161}$ Campiti found that defendants cannot claim a broader defense than that provided in the statute.

In Kilgore and Jacobson, courts found the good faith defense and pre-Harlow qualified immunity equivalent when a defendant relied on an authorization satisfying the express terms of the statutory defense. Zweibon allowed the good faith defense to be broadened to the extent of qualified immunity in order to cover national security wiretaps. Campiti did not allow the good faith defense to be so broadened in the case of normal taps. With the exception of the narrow, national security exception, qualified immunity did not apply under the statute. Zweibon and Campiti demonstrate that courts during this period

157 See 18 USC $\$ 2520$ (1970). See also Berry, 146 F3d at 1013-14 (noting the exceptional nature of cases like Halperin and Zweibon).

158611 F2d 387 (1st Cir 1979).

159 Id at 394.

160 Id, citing S Rep No 90-1097 at 107, reprinted in 1968 USCCAN at 2196 (cited in note 3) (stating that "[a] good faith reliance on a court order would constitute a complete defense to an action for damages").

$161611 \mathrm{~F} 2 \mathrm{~d}$ at 394.

162 Id at 394-95. Thus, Campiti disallowed qualified immunity based on implicit obstacle preemption analysis - permitting the use of qualified immunity contravened the purpose of the statute under the facts of the case. 
looked to the statute and congressional intent to shape the boundaries of the good faith defense. These cases implicitly employ obstacle preemption analysis, allowing qualified immunity only when doing so does not contravene the purpose of the statute. None of these cases suggests that qualified immunity should be available, as a matter of course, to wiretap defendants. After Harlow, with objective qualified immunity, the differences between the two defenses are amplified. The early FWA cases suggest that courts before 1982 did not allow qualified immunity as a FWA defense without independent justification, namely, that qualified immunity overlapped with the statutory defense (but Harlow removes the area of overlap) or that qualified immunity was allowed under the national security exception (but Congress repealed this provision). Since neither justification has survived, early FWA cases support the conclusion that qualified immunity should not be available under the FWA today.

\section{B. Good Faith Provisions in Other Statutes}

As discussed in Part I, the FWA does not expressly preclude qualified immunity, but it is a detailed statute with the principal purpose of limiting wiretaps. The FWA includes the good faith defense in order to exempt from liability a reasonably mistaken official relying on a court order. Examining the good faith defense under other statutes could clarify the FWA's provision and Congress's purpose in including it. Congress has included good faith defenses in various statutes. ${ }^{163}$ However, most of these statutes and defenses do not interact with areas of federal common law as does the FWA. Congress has included good faith defenses similar to the FWA's in two statutes that provide more direct parallels. The language of these statutes, plus court interpretations of these provisions, could provide additional clarification of the FWA's statutory defense.

The Electronic Communications Privacy Act of 1986 ("ECPA"), ${ }^{164}$ in addition to amending the FWA, provides its own cause of action against electronic communications services companies that violate the ECPA's prohibitions. ${ }^{165}$ The ECPA provides the identical good faith defense contained in the FWA. ${ }^{160}$ As the provisions are worded identi-

163 See, for example, 21 USC $\S 1905$ (c)(2) (Supp 1999) (allowing defense to the violation of the statute or regulations designed to facilitate the investigation of international narcotics trafficking for actions taken in good faith to carry out such investigations); 8 USC $\$ 1324 a$ (a)(3) (1994 \& Supp 1996) (allowing defense to prohibition on employing unauthorized aliens if defendant has attempted to comply in good faith with the statute's procedures); 16 USC $\$ 1540$ (a)(3) (1994) (allowing defense to prohibitions on harming endangered wildlife for actions taken in good faith belief that such actions were necessary to prevent bodily harm of an individual).

16418 USC $\$ 2701$ et seq (1994 \& Supp 1996).

165 See 18 USC \$ 2707(e).

166 Compare id $\$ 2707$ (e) (ECPA) with id $\$ 2520$ (d) (FWA). 
cally, courts' interpretation of the ECPA provision could provide guidance to courts interpreting the FWA.

Few courts have interpreted the ECPA provision. Davis $v$ Gracey $^{167}$ adjudicated the good faith defense of the ECPA based on an objective standard: "To be in good faith, the officers' reliance must have been objectively reasonable." involved a Section 1983 claim and qualified immunity. ${ }^{169}$ Surely, using an objective standard to adjudicate a good faith statutory defense is incorrect. If Congress intended the ECPA defense to mirror qualified immunity, it could have simply parroted those terms in defining the defense. Good faith has a commonly accepted legal meaning, which indicates that a court should apply a subjective standard, not objective qualified immunity. ${ }^{170}$

The Privacy Protection Act of 1980 ("PPA") good faith defense: "It shall be a complete defense to a civil action [against a government officer or employee] that the officer or employee had a reasonable good faith belief in the lawfulness of his conduct." ${ }^{172}$ This provision is not directly parallel because the PPA authorizes suits primarily against state or federal government entities; state employees may only be sued if the state has not waived its sovereign immunity. ${ }^{173}$ One case that applied this provision concluded that the statute did not authorize suits against municipal employees, the defendants in the case. ${ }^{174}$ Another case found that qualified immunity would only be available as a defense to suits against individuals, not government entities. ${ }^{175}$ Thus, no courts have parsed the boundaries between the PPA's good faith defense and qualified immunity. Congress has not employed a statutory good faith defense in other contexts that inform Section 2520. Neither the ECPA nor the PPA resolves the tension between the good faith defense and qualified immunity.

167111 F3d 1472 (10th Cir 1997).

168 Id at 1484.

169 Id, citing Malley v Briggs, 475 US 335, 344-45 (1986).

170 See Part I.C.

17142 USC $\$ 2000$ aa et seq (1994 \& Supp 1996).

172 Id $\S 2000 \mathrm{aa}-6$ (b) (1994).

173 See id \& 2000aa-6(a)(2). Suits against state employees are only permitted if the state has not waived its sovereign immunity. If the state waives its immunity, the plaintiff must sue the state and not the individual. See also Davis, 111 F3d at 1481-82 (dismissing PPA cause of action for lack of subject matter jurisdiction because plaintiff did not sue a state or federal governmental entity); Citicasters, Inc v Mc Caskill, 883 F Supp 1282, 1292 (W D Mo 1995) (finding in PPA suit against government entity that neither prosecutorial immunity nor qualified immunity is permitted as a defense), revd on other grounds, 89 F3d 1350 (8th Cir 1996).

174 Davis, 111 F3d at 1482 (dismissing suit for lack of subject matter jurisdiction).

175 Citicasters, 883 F Supp at 1292. 
The older cases demonstrate that, outside the national security context, courts found the good faith defense and qualified immunity to be largely equivalent but nonetheless adjudicated them separately when qualified immunity appeared to offer a broader defense. Other statutes are not particularly helpful. These sources inform the statutory preclusion question, but do not provide an answer.

\section{QUALIFIED IMMUNITY SHOULD BE PRECLUDED UNDER THE FWA}

None of the FWA cases that have considered qualified immunity under the statute fully considers or sufficiently resolves the questions of statutory preclusion and overlap. This Part considers the cases and statute in light of the FWA's clear purpose to prohibit unauthorized wiretaps. As allowing qualified immunity would contravene the purpose of the FWA, courts should utilize obstacle preemption analysis and prohibit the use of qualified immunity under the FWA.

\section{A. The Purpose and Legislative History of the FWA Argue against Allowing Qualified Immunity}

One principal technique of statutory interpretation is to examine a provision in light of the purpose of the statute as a whole. Courts generally acknowledge that the purpose of the statute is a key tool in statutory interpretation. ${ }^{176}$ Courts consider the purpose of a statute of paramount consideration in interpreting its provisions and scope. Interpreting a statute in accordance with its purpose reflects judicial deference to legislators: "Sound rules of statutory interpretation exist to discover and not to direct the Congressional will." Purpose may be used to broaden or narrow statutory language. ${ }^{178}$ The primacy of statutory purpose underlies obstacle preemption analysis. ${ }^{179}$ If a statute's purpose is clear, courts that employ obstacle preemption consistent with that purpose further Congress's goals and the success of the statute.

176 See, for example, Holloway v United States, 526 US 1, 9 (1999).

177 Moskal v United States, 498 US 103, 117 (1990) (citations omitted).

178 See Associated Electric Cooperative, Inc v United States, 226 F3d 1322, 1326 (Fed Cir 2000) (finding that purpose of Federal Insurance Contributions Act to tax a "broad range of employer-furnished remuneration" directs court to employ broad definitions of "wage" and "employee" in determining whether employer owed Social Security taxes on voluntary early retirement payments); Ingram v Muskogee Regional Medical Center, 235 F3d 550, 552 (10th Cir 2000) (discussing narrow interpretation of "appropriate medical screening" as most appropriate to purpose of Emergency Medical Treatment and Active Labor Act).

179 See Part I.D.

180 See McGreal, 45 Case W Res L Rev at 834 (cited in note 76) (stating that obstacle preemption, when undertaken along with ascertainable statutory purpose, promotes a more successful statutory scheme). 
While, in general, statutes are interpreted to preserve common law meanings and doctrines, that presumption does not survive if contrary to the purpose of the statute. ${ }^{181}$ This principle underlies obstacle preemption analysis. "Congress' general purpose in enacting a law may prevail over [the common law meaning] rule of statutory construction." statute to trump common law presumptions concerning the right of a discharged seaman to wages under the Shipping Commissioners Act, ${ }^{183}$ director liability standards under the Financial Institutions Reform, Recovery, and Enforcement Act of $1989,{ }^{184}$ and standards as to train speed and warning devices under the Federal Railway Safety Act of $1970 .^{185}$ The Supreme Court has declined to expand the applicability of a statutory defense when contrary to the purpose of the statute. ${ }^{186}$ The purpose of the statute approach suggests a resolution of the qualified immunity question under the FWA.

The purpose of the FWA, as reflected by the plain language of the statute, is to discourage unauthorized wiretapping and disclosure of the content of a wiretap. ${ }^{187}$ Allowing officials to assert qualified immunity contravenes the goal of the statute, to prohibit unauthorized wiretaps. The statute's comprehensive regulation of wiretapping confirms that the purpose of the statute is to deter government activity in this area. The FWA thus has a clear purpose that courts should not hesitate to further through the use of obstacle preemption.

Further, Congress enacted this purpose with detailed provisions. Congress detailed every aspect of the use and authorization of wire-

181 See, for example, Jones $v$ Federated Financial Reserve Corp, 144 F3d 961, 965-66 (6th Cir 1998) (finding common law theory of apparent authority vicarious liability consistent with the purpose of the Fair Credit Reporting Act, and therefore appropriately used as an "operative theory of liability" under the statute).

182 Moskal, 498 US at 117 (reading "falsely made" in accordance with Congress's broad purpose underlying 18 USC $\$ 2314$, prohibiting the trafficking of falsely made securities, rather than the common law meaning of the term).

183 See Isbrandtsen Co v Johnson, 343 US 779, 788-89 (1952) (finding that a listing of specific wage deductions in the Shipping Commissioners Act evinced the purpose to exclude additional, common law deductions).

184 See Resolution Trust Corp v Camhi, 861 F Supp 1121, 1127 (D Conn 1994) (finding statutory preemption of the federal common law negligence standard for director liability in financial institutions).

185 See Waymire $v$ Norfolk and Western Railway Co, 65 F Supp 2d 951, 957 (S D Ind 1999) (finding that the Federal Railway Safety Act preempts federal common law negligence standards as to train speed and warning devices).

186 See Albermarle Paper Co v Moody, 422 US 405, 444 (1975) (Rehnquist concurring) (construing good faith defense to Equal Employment Opportunity Act claim narrowly, consistent with Congress's intent as to scope).

187 See generally 18 USC $\$ 2511$. 
taps, and authorized civil suits to enforce the prohibition. ${ }^{188}$ Thus, the statute should not be open to judicial augmentation. ${ }^{189}$

Courts have consistently found a clear purpose in the FWA to limit the ability of government officials to use wiretapping to intrude on the privacy of the general public. "[T]he legislation therefore specifically put strict limits on wiretapping and on how it could be used.... In construing the statute, it should always be remembered that 'although Title III authorizes invasions of individual privacy under individual circumstances, the protection of privacy was an overriding congressional concern." "190 Finally, the statute imposes elaborate safeguards to deter abuse and embodies congressional intent to curtail wiretapping. ${ }^{191}$

Allowing an objective qualified immunity defense under the FWA does not conform with the purpose of the statute, and thus qualified immunity should be preempted as an obstacle to the statute's purposes. Because of the procedural differences between the two defenses discussed in Part I.C, allowing a defendant to assert qualified immunity reduces the probability that the case will survive summary judgment or even a motion to dismiss. Thus, the deterrent effect of allowing civil suits for violations of the FWA protections could be compromised by allowing qualified immunity. Further, even if the defendant cannot utilize qualified immunity, he will be able to defeat the suit at trial if the factfinder determines that he acted in good faith reliance on a court order or other authorization. This means that the defendant will not be left without protection.

The legislative history of the FWA supports this interpretation. The Senate Report to the Omnibus Crime Control and Safe Streets Act of 1968 demonstrates the FWA's primary purpose: to prevent all wiretapping other than that duly authorized by law enforcement officials. ${ }^{102}$ According to the report, ${ }^{193}$ the legislation codifies the standards

188 See id $\S \$ 2516-19$.

189 See, for example, FDIC v Ornstein, 73 F Supp 2d 277, 283-84 (E D NY 1999) (stating that the court's job in the face of a detailed statute is to construe the statute rather than fashion its own rule). See also O'Melveny \& Myers v FDIC, 512 US 79, 85 (1994) (stating that it is inappropriate to "adopt a court-made rule to supplement federal statutory regulation that is comprehensive and detailed").

190 National Broadcasting Co v United States Department of Justice, 735 F2d 51, 53 (2d Cir 1984), quoting Gelbard $v$ United States, 408 US 41, 48 (1972).

191 Gelbard, 408 US at 50 (quoting congressional findings that state, "it is necessary for Congress to define [the] ... conditions under which the interception of [electronic] communications may be authorized, [and] to prohibit any unauthorized interception of such communications").

192 S Rep No 90-1097 at 89, reprinted at 1968 USCCAN at 2177 (cited in note 3) ("all unauthorized interception of such [wire or oral] communications should be prohibited").

193 S Rep No 90-1097 at 28, reprinted at 1968 USCCAN at 2113 (cited in note 3). 
set out in Berger $v$ New York ${ }^{194}$ and Katz $v$ United States. ${ }^{195}$ In Berger, the Supreme Court invalidated a New York statute that authorized overly broad eavesdrop orders. ${ }^{196}$ In $\mathrm{Katz}$, the Supreme Court refused to admit evidence the FBI obtained from a wiretap that had not been authorized by any judicial order. ${ }^{197}$ The report further indicates that Section 2520 was intended to provide a comprehensive and exclusive remedy, but that a "good faith reliance on a court order would constitute a complete defense." ${ }^{198}$ Thus, the report indicates a clear congressional signal to restrict the ability of government officials to wiretap the general public, but provide a defense to officials who acted in good faith reliance on a court order.

Subsequent amendments demonstrate Congress's expansion of the causes of action and clarification of the defense. The legislative history to the 1986 amendment to the FWA, the ECPA, signals Congress's intent to broaden the provisions authorizing civil suits to include suits for "interception, disclosure or intentional use of wire, oral, or electronic communications."

\section{B. Similar Statutes}

This Comment's approach has been employed to find qualified immunity unavailable under other statutes. The False Claims Act ("FCA") was passed in 1863 to discourage fraud against the government and encourage those with knowledge of such fraud to come forward. ${ }^{200}$ In light of the statute's clear purpose to encourage reporting fraud, the Fifth Circuit in Samuel $v$ Holmes ${ }^{201}$ found that qualified immunity should not be available as a defense against FCA claims. ${ }^{202}$ The court found qualified immunity precluded notwithstanding legislative silence as to the availability of qualified immunity because "[g]ranting government officials the protection of qualified immunity would hardly spur reluctant employees to step forward." ${ }^{203}$ Samuel employed obstacle preemption analysis and found the defense contrary to Congress's purpose. The court reached this conclusion despite the Supreme Court's signal that qualified immunity should apply broadly

194388 US 41 (1967).

195389 US 347 (1967).

196388 US at 44.

197389 US at 358-59.

198 S Rep No 90-1097 at 107, reprinted at 1968 USCCAN at 2196 (cited in note 3).

199 Electronic Communications Privacy Act of 1986, S Rep No 99-541, 99th Cong, 2d Sess 26.

200 See 31 USC $\$ 3729$ et seq (1994).

201138 F3d 173 (5th Cir 1998).

202 Id at 178.

203 Id. 
and should be available unless Congress explicitly indicated the contrary. The court's reasoning reflects a common sense notion of statutory purpose. When a statute, like the FCA, indicates a clear purpose, courts should not allow qualified immunity to defeat that purpose. Courts should use obstacle preemption analysis to trump provisions of the federal common law that are inconsistent with the statute's purpose. $^{204}$

Samuel's approach is consistent with generally accepted notions of statutory interpretation. ${ }^{205}$ Using the purpose of the statute as a factor to be considered when a court evaluates whether qualified immunity should be available as a defense against a cause of action has found further support in the context of the Americans with Disabilities Act ("ADA"). ${ }^{206}$ Congress's purpose in passing the ADA was "to provide a clear and comprehensive national mandate for the elimination of discrimination against individuals with disabilities." ${ }^{207}$ That purpose may be inconsistent with allowing qualified immunity. ${ }^{208}$ Further, the ADA is detailed; the original statute contained five subtitles and fifty-nine separate sections. ${ }^{209}$ Thus, the need for augmentation through judicial interpretation is minimal.

Despite the statute's purpose and detail, several courts have nonetheless allowed qualified immunity as a defense to ADA claims. ${ }^{210}$ Apparently most courts have not even considered the possible arguments for disallowing qualified immunity under the statute. The Seventh Circuit appears open to the question of whether qualified immunity is appropriate under the ADA, because of the detail in that law. ${ }^{211}$

204 See United States $v$ Texas, 507 US 529, 534 (1993) (stating that common law principles should be applied except when there is a contrary statutory purpose); City of Milwaukee v Illinois, 451 US 304, 314 (1981) (noting that federal common law should only be applied in the "absence of an applicable Act of Congress"). See also Part I.D.

205 See, for example, Holloway v United States, 526 US 1, 9 (1999) (stating that statutory language should be interpreted consistent with the provisions of the whole law and "its object and policy"), quoting John Hancock Mutual Life Ins Co v Harris Trust and Savings Bank, 510 US 86, 94-95 (1993).

206 See Gary S. Gildin, Dis-Qualified Immunity for Discrimination against the Disabled, 1999 U Ill L Rev 897, 928-29 (finding that qualified immunity conflicts with the broad compensatory purpose of the ADA, the Rehabilitation Act, and the Individuals with Disabilities Education Act).

207 Id at 905, citing 42 USC $\$ 12101$ (b)(1) (1994).

208 See Walker v Snyder, 213 F3d 344, 346 (7th Cir 2000) (Easterbrook) (pondering, without deciding, the appropriateness of allowing qualified immunity as a defense to ADA claims).

209 See Americans with Disabilities Act of 1990, Pub Law No 101-336, 104 Stat 327, codified at 42 USC $\S 12101$ et seq (1994).

210 See, for example, Hall v Thomas, 190 F3d 693, 696-97 (5th Cir 1999); Gorman v Bartch, 152 F3d 907, 914-16 (8th Cir 1998).

211 Walker, $213 \mathrm{~F} 3 \mathrm{~d}$ at 346 (stating that "[a]lthough several decisions have held or assumed that individual defendants are entitled to qualified immunity in ADA litigation ... none of these decisions discussed whether it is sound to extend immunity principles from litigation under 42 U.S.C. $\S 1983$ to suits under more recent, and more detailed, laws"). The claim was dismissed on 
Future ADA decisions may conclude that qualified immunity is not an available defense. There are clear parallels among these statutes and the FWA that justify following Samuel and the Seventh Circuit's pondered approach in ADA litigation. The FWA, like the False Claims Act, contains a strong prohibition against the covered activity, inconsistent with allowing qualified immunity. ${ }^{212}$ Further, the FWA, like the ADA, is a detailed statute. ${ }^{213}$

\section{The Policy Reasons for Objective Qualified Immunity Do Not Apply in FWA Cases}

The policy considerations underlying the Supreme Court's decision in Harlow, switching qualified immunity to the objective standard, ${ }^{214}$ are not present under the FWA. The focus of the FWA is restricted to a narrow class of cases, ${ }^{215}$ similar in scope to the FCA. ${ }^{216}$ By way of contrast, Section 1983 and Bivens are extremely broad, allowing civil suits against government officials who violate any constitutional right. ${ }^{217}$ This breadth led the Supreme Court to make the policy choice of an objective standard for qualified immunity to avoid lengthy litigation on a host of patently frivolous constitutional claims. Since the FWA does not have the same scope, qualified immunity need not apply for the same reasons.

Congress wrote Section 1983 with breadth and generality, such that courts have been required to fill in the details of how cases should be administered. ${ }^{218}$ Because of the fear that a plethora of Section 1983 suits would result in government paralysis, courts have made qualified immunity easier to satisfy. The generosity of qualified immunity in the Section 1983 context is, in part, the result of the large quantity of suits that the statute generates.

alternate grounds and the court did not address the question. Id.

212 See Part IV.A.

213 Compare 42 USC $\$ 1983$, which includes just over one hundred words.

214 See text accompanying notes 34-38.

215 For a general discussion of the scope of the FWA, see Part I.B.

216 See Part IV.B.

217 See Part I.A.

218 See Koehn, 32 U Mich J L Ref at 56 (cited in note 20) ("Section 1983's breadth is part of its strength, but it also operates as a weakness. Because Congress wrote the statute with such generality, the Court has been free, if not required, to fill in the details.").

219 According to the government, 36,640 civil rights cases involving federal questions (which would include both Section 1983 and Bivens suits) were filed by private parties during 2000 and 13,415 civil rights cases were filed by prisoners. See 2000 Annual Report of the Director, Judicial Business of the United States Courts 2000, Table C-2, available online at http://www.uscourts.gov/judbus2000/appendices/c02sep00.pdf (visited Sept 8, 2001). These statistics simply indicate filings and overstate the number of bona fide civil rights suits. See Theodore Eisenberg and Stewart Schwab, The Reality of Constitutional Tort Litigation, 72 Cornell L Rev 641, 665-66 (1987). However, the magnitude of cases speaks for itself. A Lexis search of all fed- 
While the Court in Harlow sought to correct a perceived imbalance between the needs of plaintiffs and defendants, some scholars have criticized elimination of the good faith standard. The current qualified immunity regime may remove the check on government behavior that Section 1983 was designed to provide and the incentive for states to improve their behavior. "The more the Court cuts back on the feasibility of a victory by Section 1983 plaintiffs, the more it weakens or even eliminates these incentives. ${ }^{920}$ Furthermore, in hoping to minimize costs, the Supreme Court may have generated unintended externalities, such as removing incentives to learn about and comply with the law.

The narrow nature of the FWA and its detailed standards provide much less opportunity for abuse by potential plaintiffs. If a citizen desired to harass the government through frivolous suits, it is highly unlikely that he would use the FWA. Importantly, he would have had to be wiretapped. Suits under the FWA, a narrow and detailed statute, provide less opportunity for interference with legitimate government operations. Many of the policy reasons that have resulted in the expansion of qualified immunity simply do not apply to the FWA.

Because the purpose of the FWA statute is inconsistent with qualified immunity, courts should preempt it using obstacle preemption analysis. When a statute's purpose is contrary to a common law standard, there is no presumption that that standard should apply. ${ }^{222}$ The distinctions between the two statutes discussed above, namely the FWA's narrow focus, detail, and purpose to deter unauthorized wiretaps, suggest that qualified immunity in its current incarnation is inconsistent with the rationale of the FWA. Qualified immunity is intended to strike a balance between vindicating individual rights and the public interest in allowing officials to focus on their duties without the harassment of frivolous suits. ${ }^{223}$ While Congress did not include any interpretive guidance as to why it included the good faith defense in the statute, its inclusion, combined with the comprehensive, uniform standards set out in the law, provides some structural inference. Since

eral courts for the terms "2520" (the FWA provision authorizing damage suits) and "wiretap" found 514 cases from 1968 to 2001. Notwithstanding the data issues related to civil rights suits, the contrast between thousands of cases filed per year and 514 cases with decisions in thirty-four years is obvious.

220 Koehn, 32 U Mich J L Ref at 98 (cited in note 20).

221 See, for example, Mandery, 17 Harv J L \& Pub Pol at 513 (cited in note 39) (arguing that the motivating concern of the Supreme Court with respect to qualified immunity and high-level government officials has left lower-level government officers with no motivation "to ascertain or comply with the law governing their conduct").

222 See United States $v$ Texas, 507 US 529, 534 (1993) (noting that to abrogate a prior common law standard a contrary purpose is sufficient).

223 See Harlow, 457 US at 813-14 (finding that qualified immunity strikes a balance between competing interests). 
the FWA includes its own defense, the statute as enacted reflects Congress's judgment about the proper balance between those competing interests in the wiretap context. Allowing qualified immunity under the FWA merely tips the scale in favor of FWA defendants.

Courts should not upset the internal equilibrium of the FWA. Unauthorized wiretapping is not a substantive area in which courts should be quick to tip the balance in favor of defendants. Uncertainty in the boundaries of allowable legal surveillance led to abuses under the FWA's original national security exception, which was repealed for that reason. ${ }^{22}$ Officials should exercise this surveillance power with care. If defendants face a larger risk of undergoing discovery and trial, they are more likely to be careful in obtaining authorizations for wiretapping. Without qualified immunity, officials would have greater incentives to educate themselves about the law. ${ }^{225}$ Government surveillance of citizens is not an area in which officials should be stretching the boundaries of the law. Congress recognized this in the original FWA: "To safeguard the privacy of innocent persons, the interception of wire or oral communications ... should be allowed only when authorized by a court of competent jurisdiction and should remain under the control and supervision of the authorizing court."226 In accordance with congressional purpose, courts should not read the liberal defense of qualified immunity into the FWA.

Furthermore, disallowing qualified immunity under the FWA does not leave government officials without protection. The statute provides the good faith defense, which officials would be free to assert even absent qualified immunity. As discussed above, they would likely be forced to undergo more rigorous discovery and possibly trial in the absence of a qualified immunity defense. However, if a defendant satisfied the good faith defense under Section 2520(d), there would be no liability. Therefore the police chief in Blake who recorded the conversations of his employees would not be able to win summary judgment, but, if the court found he acted in good faith reliance on statutory (or other) authorization, he would not face liability. ${ }^{227}$ The police chief in

224 See Part III.A; Ronald G. Carr, In Honor of Edward H. Levi, 52 U Chi L Rev 300, 30304 (1985) (discussing the executive branch's questionable conduct in warrantless national security wiretaps before 1975). See also United States v United States District Court, 407 US 297, 314 (1972) (proscribing warrantless national security wiretaps of domestic groups because of the threat to individuals who merely have unorthodox political beliefs).

225 See Mandery, 17 Harv J L \& Pub Pol at 481 (cited in note 39) (stating that qualified immunity departs from the norm that all citizens are strictly liable for knowledge of the law).

226 S Rep No 90-1097 at 11, reprinted in 1968 USCCAN at 2156 (cited in note 3). The legislative history provides even stronger language: "No one quarrels with the proposition that the unauthorized use of [wiretapping] techniques by law enforcement agents should be prohibited."

227 Blake, 179 F3d at 1006. 
Tapley who intercepted a cordless phone conversation and shared his tape with other city employees could also assert the good faith defense. ${ }^{228}$ The defendants in Berry could also have asserted the good faith defense, but apparently chose not to do so. ${ }^{229}$ Thus, these defendants would not automatically lose their cases absent qualified immunity.

\section{CONCLUSION}

The FWA good faith defense and common law qualified immunity utilized the same standard until 1982. Harlow then changed only qualified immunity to an objective standard. If courts allow qualified immunity under the FWA, defendants will be far more likely to secure dismissal of suits before discovery or trial, which could reduce the deterrent effect of allowing civil suits under the FWA. Allowance of qualified immunity under the FWA also is inconsistent with the statute's purpose of limiting the government's ability to wiretap. Courts should employ obstacle preemption analysis to trump qualified immunity under the FWA.

Disallowing qualified immunity does not leave defendants without any protections if they attempted to comply with the statute. If courts restrict qualified immunity under the FWA, defendants may still assert the statutory good faith defense. Defendants would then face more incentives to comply with the law. Government surveillance of citizens is not an area in which officials should push the boundaries of the law. 